\title{
ROMAN POSLJEDNJI STIPANC̆IĆI VJENCESLAVA NOVAKA U SREDNJOŠKOLSKOJ NASTAVI KNJIŽEVNOSTI
}

\author{
Jadranka Jerčinović \\ Intelekt - ustanova za srednjoškolsko obrazovanje, \\ osposobljavanje, usavršavanje \\ i ostalo obrazovanje odraslih \\ Korzo 2A/I \\ HR 51000 Rijeka \\ jadranka.jercinovic@gmail.com \\ Emilija Reljac Fajs \\ Učiteljski fakultet Sveučilišta u Rijeci \\ Sveučilišna avenija 6 \\ HR 51000 Rijeka \\ emilija@ufri.hr
}

UDK: $82: 371.3$

\author{
821.163.42.09Novak, V. \\ Stručni članak \\ Ur.: 2020-1-24
}

U povijesti hrvatske književnosti Vjenceslav Novak predstavljen je kao realistički pisac primorske sredine, s naglaskom na njegovo podrijetlo, rad u školi, materijalne životne uvjete i tematiku koju je uglavnom uzimao iz stvarnoga svijeta. Novak je objektivan realistički pripovjedač jer ne uzdiže ni ne prezire, no istodobno i socijalno osjećajan jer je prvi u hrvatski realizam unio ljubav prema obitelji i jeziku kojim je stvarao roman pod naslovom Posljednji Stipančići. Očito je ljepota odabranih riječi pridonijela da se tijekom cijeloga pripovijedanja porodične pripovijesti o Stipančićima osjećaju sigurni potezi piščeva pera, bilo da o njoj pripovijeda kronološki ili retrospektivno.

Kritika realizma nije imala razumijevanja za ogroman Novakov opus kao rezultat jedne osebujne umjetničke stvaralačke snage. Moderna hrvatska književna kritika prikazala je rast Novakova opusa kroz četiri koncentrična kruga. Budući da je svako književno djelo poseban suodnos svijeta koji umjetnik prikazuje i jezika kojim o tom svijetu piše, logična je povezanost Novakove socijalne i jezične osjećajnosti dok je pripovijedao životnu priču obitelji svojega doba. U suvremenoj književnoj kritici roman Posljednji Stipančići proglašen je najboljim romanom hrvatskoga realizma, zastupljen je u srednjoškolskoj nastavi književnosti, a prošle školske godine i na državnoj maturi.

Ključne riječi: obiteljski roman, realistička metoda, rječnik, socijalna osjećajnost 


\section{Novak u povijesti i kritici književnosti}

U povijesti hrvatske književnosti Vjenceslav Novak (1859. - 1905.) predstavljen je kao realistički pisac iz Hrvatskoga primorja, s naglaskom na doseljeničko podrijetlo jer mu je otac bio iz češke, a majka iz bavarske obitelji. Pored podrijetla odredili su ga kao pisca i skromni materijalni uvjeti u kojima je živio kao prosvjetni radnik s velikom obitelji, zbog koje se često morao seliti, ali i ubrzano pisati. Njegov književni opus je ogroman, a Antun Barac ga je podijelio u četiri tematska kruga: rodni Senj i okolica, Podgorje, građanska i malograđanska sredina te svijet obespravljenih i prezrenih.

Bez obzira na tematske krugove, Novak se kao čovjek i kao pisac najčešće držao svijeta i ljudi kojima je i sam pripadao, pa u njegovu opusu dominiraju djela obilježena socijalnom osjetljivošću. Spletom životnih i stvaralačkih okolnosti pisao je ponekad prebrzo te su mu neke proze u kritici ocijenjene kao znatno slabije, a isto tako vidljive su oscilacije u kvaliteti i unutar njegovih boljih djela. Istina je da Novak nije bio miljenik kritike svoga doba, mnogima nezanimljiv i nepoznat, no to ne umanjuje njegovo značenje u hrvatskoj književnosti realizma. Tek je u suvremenoj hrvatskoj književnoj kritici rečeno kako je upravo Vjenceslav Novak napisao "najbolji roman hrvatskoga realizma."1

Novaka je zanimala stvarnost, odnosno društveni svijet u kojemu stvarni čovjek zbog održanja gologa života neminovno dolazi u sukob sa sredinom. Konflikt junaka i sredine, kojoj je i sam pripadao, Novakova je najjača inspiracija jer se ni osobno nije mogao afirmirati kao pisac. Prvu pohvalu njegova djela dao je pjesnik Silvije Strahimir Kranjčević rekavši kako je Novak "posve blizu običnom životu" jer je "svoju tintu kupio u kramara, nije ju miješao ni parfumirao." 2 Bila je to istodobno i kritika onim piscima koji su pisali u toplini doma, "dugo u noć", jer su danju boravili po gospodskim salonima i dodvoravali se bogatašima ili vlastodršcima. Za razliku od većine hrvatskih realista, Novak je tematici pristupao objektivno i nepristrano, bez posebnoga udjela vlastitoga ideološkog ili političkog opredjeljenja. Najbolji dio njegova književnoga opusa inspiriran je senjskim i podgorskim životom, a čine ga djela Pod Nehajem, Podgorka, Posljednji Stipančići i Tito Dorčić. U tim djelima Novak je kroz pojedinačne sudbine malog čovjeka vlastitoga podneblja prikazao cjelovitu i neuljepšanu stvarnu sliku života ljudi u Hrvatskoj u devetnaestom stoljeću.

${ }^{1}$ K. NEMEC, 1994, 225.

${ }^{2}$ S. S. KRANJČEVIĆ, 1964, 151. 


\section{Roman Posljednji Stipančići u nastavi književnosti}

U romanu Posljednji Stipančići Vjenceslav Novak pripovijeda o totalnoj propasti patricijske obitelji, ali tako da kroz svakoga člana obitelji oslikava jedan vid propadanja.

Otac Ante Stipančić, bivši okorjeli zastupnik senjskih patricija, ali i obiteljski despot, na kraju umire kao svaki drugi osiromašeni starac. Njegov sin Juraj, kojeg je favorizirao jer je u njemu gledao svojega nasljednika, postaje propalica, izdajnik vlastite obitelji i naroda. Kao posljednji izdanci nekada imućne senjske obitelji ostaju žene koje životare u neimaštini i samoći. Žena i majka Valpurga te kćerka i sestra Lucija egzistiraju kao predstavnički likovi poniženih i totalno obespravljenih ljudi. Posebno je istinski tragičan i fascinantan lik Lucije koja je tek u suvremenoj hrvatskoj književnoj kritici determinirana kao "najprodubljeniji i najsloženiji ženski lik čitave hrvatske književnosti 19. stoljeća". ${ }^{3}$ Iako Lucija nije glavni lik romana, ona se izdiže iznad svih žena u hrvatskoj književnosti kao introvertirana i senzibilna heroina prostora i vremena u kojima je morala egzistirati.

Roman Vjenceslava Novaka Posljednji Stipančići zastupljen je u nastavnim programima i čitankama za srednje škole u Hrvatskoj. Prošle školske godine $^{4}$ taj je roman bio zastupljen i na državnoj maturi kao esejski zadatak - usporedna raščlamba tekstova, što potvrđuje da je uistinu riječ o vrhunskom djelu hrvatske književnosti.

Novakov roman se, kao i svako lektirno književno djelo predviđeno za čitanje u cijelosti, interpretira kada ga učenici pročitaju kao domaću lektiru. Nastavna interpretacija proznih djela standardno obuhvaća dojmove čitatelja, tematiku, kategorije mjesta i vremena zbivanja, fabulu, likove, kompoziciju, stil i jezik. Iznoseći svoje dojmove o djelu učenici ga i povezuju sa sličnim književnim djelima u hrvatskoj, europskoj i svjetskoj književnosti. Nakon lokalizacije romana slijedi detaljna interpretacija prema ustaljenom metodičkom sustavu. Iako metodika nastave književnosti poznaje različite metodičke sustave, u interpretativno-analitičkom sustavu "književno djelo postaje temeljnim

${ }^{3}$ K. NEMEC, 1994, 231.

${ }^{4}$ Posljednji Stipančići pojavili su se kao esejski zadatak i na državnoj maturi 2016./2017., ponovno u usporednoj raščlambi tekstova s ulomkom iz pripovijetke Duga Dinka Šimunovića. Predložene smjernice uključivale su predstavljanje romana Posljednji Stipančići u kontekstu književnopovijesnoga razdoblja u kojemu je nastao, portretiranje Lucije Stipančić na temelju djela u cjelini, usporedbu polaznih tekstova, tumačenje kako odgoj i društvena sredina određuju živote žena te obrazlaganje tvrdnji. Prije toga pojavili su se i 2011./2012. (interpretativni esej), 2012./2013. (usporedna raščlamba tekstova) i 2015./2016. (usporedna raščlamba tekstova). 


\section{ZADATAK ZA PISANJE ŠKOLSKOGA ESEJA}

\section{Prvi polazni tekst}

Honoré de Balzac, Otac Goriot

Odgoj je njegovih kćeri, dakako, bio bezuman. Posjedujući više od šezdeset tisuća livara rente i trošeći na sebe manje od tisuću i dvjesto franaka, Goriot je sreću nalazio u tome da udovoljava hirovima svojih kćeri: najvrsnijim je učiteljima bila povjerena zadaća da ih obdare znanjima koja pokazuju dobar odgoj; imale su družbenicu; srećom za njih bila je to žena koja je imala i duha i ukusa; bavile su se jahanjem, imale kočiju, živjele kao što bi živjele ljubavnice nekoga staroga bogatog velikaša, bilo je dovoljno samo da izraze najskuplje želje, a otac je žurio da im ih ispuni; tražio je tek poljubac kao uzvrat za svoje poklone. Goriot je kćeri uzdizao u red anđela, pa nužno i iznad sebe, te je - jadni čovjek! - volio čak i samo zlo što su mu ga one nanosile. Kada su mu kćeri dorasle za udaju, smjele su izabrati muža po svom ukusu: svaka je imala kao miraz dobiti polovicu očeva imetka. Anastasie je, kojoj je zbog njezine ljepote udvarao grof de Restaud, imala aristokratske sklonosti koje su je navele na to da napusti očevu kuću i da se vine u visoke društvene sfere. Delphine je voljela novac: udala se za Nucingena, bankara njemačkog podrijetla koji je postao barunom Svetoga Carstva. Goriot ostade proizvođač rezanaca.

\section{Drugi polazni tekst}

\section{Vjenceslav Novak, Posljednji Stipančići}

Luciji se htjelo života i slobode, njezina je duša hrlila neobuzdano za probuđenim osjećajima djevojačke sreće što se rađala iz njezine mladosti. Ona je već razumjela muške oči što su se otimale za njom i živjela u neprekidnom čeznuću da bude viđena među prvima. (...)

I koliko je to njezino čeznuće za odličnim društvom i zabavama, što bi in sad građani, a sad časnici davali, bilo neobuzdano, opet ga je neumoljivo sapinjala tvrdokorna vlast oca. Nije htio ni da čuje za kakove izdatke na njezina odijela i gdjekada upravo surovo uskraćivao i neznatne troškove što bi in za nju mati od njega tražila. Da uskrati novac, on bi našao sto razloga i napokon predbacivao Valpurgi da je iskvarila to dijete puštajući mu preko očeva znanja koješta na volju. Htio je pako da Lucija boravi u njegovoj sobi te mu čita, a on je podučava, kako bi tvrdio, u onome što će joj danas sutra vrijediti daleko više nego misli na kojekakve ludorije što ih može da zamisli ženska ispraznost.

Nelijepo, zlobi nalik čuvstvo proti ocu mučilo bi gdjekada Luciju, a to nije mogla da zataji ni njemu ni majci. Izravno mu toga dašto nije smjela reći; ali je Stipančić pogađao da je njezina pokornost i uslužnost prema njemu usiljena. Majci pako nije skrivala to svoje čuvstvo napram ocu; kad bi joj rekla da otac želi neka dođe u njegovu sobu, smračila bi lice:

- Idem, kad moram. Ali da znate kako mi teško teku časovi u očevoj sobi, vi me ne bi nikada gore slali. (...)

- Velim vam, kad sam sama uza nj, meni su svezana usta. Što bih s njime govorila, kad zna da mi nije pravedan? Zar nisam odrasla pa i danas još zatvorena u ovim tamnim sobama kao u samostanu? Neka pogleda moje vršnjakinje kakvi im je život, pa će vidjeti govorim li pravo.

\section{Smjernice}

- Predstavite poetiku djela Otac Goriot i poetiku djela Posljednji Stipančići.

- Usporedite oca Goriota i Antu Stipančića na temelju djela u cjelini.

- Usporedite polazne tekstove na tematskoj, problemskoj i stilskoj razini.

- Povežite problematiku polaznih tekstova s književnim djelima slične problematike.

- Obrazložite svoje tvrdnje.

Sl. 1. Primjer zadatka za pisanje školskog eseja na državnoj maturi u ljetnom roku 2019./2020. godine - usporedna raščlamba tekstova (izvor: https://www.ncvvo.hr/ drzavna-matura-2019-2020-ljetni-rok-3/) (12-24-2019) 
sadržajem nastavnoga procesa, a interpretacija djela najvažnijim oblikom nastavnog rada." ${ }^{5}$ Središnje mjesto u takvoj interpretaciji zauzimaju naravno protagonistički likovi, a potom se opisuju i karakteriziraju sporedni, epizodni i marginalni likovi.

Novakovi Posljednji Stipančići su bez obzira na podrijetlo i društveni status tipična patrijarhalna obitelj čiji je gospodar otac Ante koji sina Jurja šalje na školovanje u inozemstvo, dok mu kćerka ne smije niti sjediti za obiteljskim stolom, a kamoli razgovarati s njim. Patrijarhalnost je bila i ostala sastavnicom svjetonazora i života u mnogim europskim i hrvatskim obiteljima, a prisutna je i "sada i ovdje", samo što se danas više govori o neravnopravnosti spolova. Lucija ne samo da kao žena nema pravo na obrazovanje nego nema pravo ni na mladenački društveni život, napose ljubav. Žena i majka Valpurga, koja obavlja kućanske poslove, završava kao prosjakinja, podsjeća na mnoge žene koje i danas u 21. stoljeću žive kao beskućnice. Dok Valpurga utjehu nalazi u vjeri, Lucija je nalazi u snovima o ljubavi koje nema te tako obje totalno obespravljene i ponižene čekaju kraj života lišenog svakog dostojanstva. Iako je roman upravo u poglavljima o ženama u patrijarhalnoj obitelji posebice "snažnog identifikacijskog naboja i emocionalnog intenziteta", tu nema očekivanih "melodramskih efekata"6, kakvi su inače poznati u mnogim prozama realizma. Budući da je upravo Lucija najveća žrtva s jedne strane materijalne i socijalne propasti obitelji Stipančić, a s druge strane patrijarhalnoga odgoja, kroz njezinu životnu priču sagledavamo i naličje građanskog morala. Lucija je zapravo istodobno i žrtva i buntovnica, no njezin bunt ne prodire kroz zidove obiteljske kuće jer je Ante Stipančić pater familias. Novakovi muški likovi jesu predstavnici Stipančića u društvu, a ne Lucija i Valpurga; one su samo sjene kao i sve obespravljene žene.

Novak je životnu priču osiromašene majke i ponižene kćerke ispripovijedao kronološki u prvom i drugom poglavlju romana, da bi potom retrospektivno ispripovijedao priču o vremenu kad su Stipančići bili bogata i slavna senjska obitelj. Autor prati život obitelji u prošlosti kroz njezine uspone i početke propasti sve do šesnaestog poglavlja, odnosno do kraja romana. Epilog porodične pripovijesti ne odvija se u kući, već na brdu Nehaj gdje Valpurga na Veliki petak od vjernika prosi milostinju. Iznova se tako potvrđuje kako "nitko među hrvatskim realistima nije uspio tako uspješno i tako uvjerljivo povezati sociološke činjenice s pojedinačnim ljudskim sudbinama kao što je to pošlo za rukom Vjenceslavu Novaku u Posljednjim Stipančićima. ${ }^{77}$ Nitko od

${ }^{5}$ D. ROSANDIĆ, 2005, 204.

${ }^{6}$ K. NEMEC, 1994, 232.

${ }^{7}$ K. NEMEC, 1994, 232. 
hrvatskih realista nije dao tako detaljnu i uvjerljivu sliku obitelji, koja propada najprije materijalno i moralno, a potom egzistencijalno, kao što je to učinio Novak. Jedini je on među hrvatskim piscima realizma uspio bez uljepšavanja i karikiranja povezati društvenu i gospodarsku krizu s krizom obitelji. Naime, njega je kao umjetnika zanimao čovjek, njegov svakidašnji život, njegova psiha, a ne drama koja se odvijala na sceni vanjskoga, odnosno globalnoga svijeta. Time je Novak među prvim piscima u hrvatskoj književnosti postao autor istinskoga, psihološkog realističkog obiteljskog romana u kojemu mnogi čitatelji, odnosno čitateljice, pronalaze sebe ili osobe iz osobnoga životnog okruženja.

\section{Stil i leksik Novakova romana}

O svakoj se sastavnici interpretacije književnoga djela raspravlja znatno više nego o jeziku. Kao glavni razlog čestoga izostavljanja jezične analize književnoga teksta navodi se nedostatak vremena s obzirom na broj nastavnih sati planiranih za pojedinoga autora, odnosno za njegovo djelo.

U kontekstu stilsko-jezične interpretacije Novakova romana uobičajeno se tvrdi da je autor životnu priču obitelji Stipančić ispripovijedao književnim jezikom razdoblja u kojem je stvarao. To je nedostatno s obzirom na to da se radi o najboljem romanu hrvatskoga realizma, odnosno o obiteljskom romanu koji svojom tematikom nadrasta i prostor i vrijeme nastanka. Budući da je Vjenceslav Novak kao istinski umjetnik birao riječi kojima je stvarao tužnu priču o jednoj senjskoj obitelji, poželjno je u kontekstu jezične analize upoznati i njegov rječnik. Naime, Novak tijekom cijeloga romana bez obzira pripovijeda li o pojedincu, obitelji ili široj sredini ne zamara svoje čitatelje jer nije ni patetičan ni bešćutan, već je duboko socijalno osjećajan. Silvije Strahimir Kranjčević je kao pjesnik i književni kritičar za Novakov obiteljski roman utvrdio da se tijekom cijelog pripovijedanja opažaju "sigurni potezi

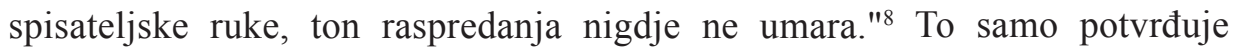
značaj riječi u književnosti, ali i senzibilitet pisca koji pripovijeda o stvarnom obiteljskom životu svojega vremena hrvatskim književnim jezikom, odnosno rječnikom. Ne smije se smetnuti s uma da je književnost umjetnost riječi, a upravo "riječ" kao temeljna jedinica jezika, koja ima "dvije vrijednosti: spoznajnu i osjećajnu"9 dolazi do punog izražaja književnom djelu. S obzirom

${ }^{8}$ S. S. KRANJČEVIĆ, 1964, 426.

${ }^{9}$ LJ. JONKE, 1964, 14. 
na činjenicu da je Novak bio senzibilan umjetnik riječi te $s$ druge strane uvažavajući riječi pjesnika Kranjčevića - vrijeme je za proučavanje rječnika ovoga romana.

Leksik obitelji Stipančić ima dvije rodne grane, odnosno dva temeljna leksička niza jer jedan pripada muškim, a drugi ženskim članovima obitelji. Posebnu pozornost treba posvetiti "riječima" kojima je autor kreirao najprodubljeniji lik žene - Lucije - u ovom obiteljskom romanu hrvatskoga realizma. Oslanjanje na jezični osjećaj nije svojstven samo umjetnicima riječi nego i drugim govornicima jezika, a posebice učenicima u nastavi književnosti zbog doživljaja i interpretacije djela. Ako je u interpretaciju svakoga književnog teksta uključen i jezik djela, onda će učenik postupno moći graditi i bogatiti vlastiti rječnik, razvijati jezični osjećaj, što će se odraziti tijekom vremena na njegov stil koji će postajati više ili manje osjećajni odnosno spoznajni. Novakov rječnik kojim je stvarao životnu priču obitelji Stipančić potvrđuje da je pripovjedač uistinu imao naglašenu i socijalnu i emotivnu osjetljivost.

\section{Zaključak}

Novakov roman Posljednji Stipančići najbolji je roman hrvatskoga realizma te je zastupljen u srednjoškolskoj nastavi književnosti i na državnoj maturi. Taj realistički roman nastao je davne 1899. godine, ali i danas se čita bez poteškoća jer je pisan jezikom koji je čitateljima razumljiv, ali i emotivno raslojen jer govori o obitelji, posebice o odnosu roditelja i djece u blagostanju i bijedi.

Novakov leksik je posebno bogatstvo jer je pisac kao obiteljski čovjek i umjetnik unio u hrvatski realizam ne samo ljubav prema obitelji nego i prema jeziku čije je riječi birao i slagao u tekst. Novak je objektivan realistički pripovjedač koji uzima tematiku iz neposrednog života ljudi svojega vremena ne uzdižući i ne podcjenjujući nikoga, no istodobno je i socijalno osjećajan. Također nije bio patetičan ni u prikazivanju propadanja plemstva, kao ni u kreiranju najsloženijeg i najprodubljenijeg lika žene u našoj književnosti Lucije, koja je simbol žrtve i pobune istodobno. Novak se najviše od hrvatskih pisaca realizma približio europskoj realističkoj književnosti, pa se često uspoređuje s Balzacom koji je također bio umješan u stvaranju umjetničkoga djela. To je u skladu s tvrdnjom da je umjetnik riječi poput slikara, glazbenika i arhitekta sklon dotjerivanju vlastitoga djela da bi uspostavio potpuni sklad između sadržaja i forme. 


\section{Literatura}

Antun BARAC, Vjenceslav Novak I - Pripovijesti. Posljednji Stipančići, Pet stoljeća hrvatske književnosti: knjiga 57, Matica hrvatska, Zora, Zagreb, 1964.

Ivo FRANGEŠ, Vjenceslav Novak danas, Riječka revija, 3-4, Rijeka, 1962.

Ivo FRANGEŠ - Milorad ŽIVANČEVIĆ, Povijest hrvatske književnosti: knjiga 4, Liber - Mladost, Zagreb, 1975.

Dubravko JELČIĆ - Vladimir VISKOVIĆ, Posljednji Stipančići Vjenceslava Novaka, Pripovijetke Slavka Kolara, Školska knjiga, Zagreb, 1996.

Ljudevit JONKE, Književni jezik u teoriji i praksi, Nakladni zavod Znanje, Zagreb, 1964. Silvije Strahimir KRANJČEVIĆ, Izabrana djela, V. Novak Posljednji Stipančići, Hrvatska književna kritika: Nehajev i suvremenici, sv. V., Matica hrvatska, Zagreb, 1964, 420-428.

Krešimir NEMEC, Povijest hrvatskog romana od početaka do kraja 19. stoljeća, Znanje, Zagreb, 1994.

Fran PETRE - Zdenko ŠKREB, Uvod u književnost, Znanje, Zagreb, 1969. Dragutin ROSANDIĆ, Metodika književnoga odgoja, Školska knjiga, Zagreb, 2005. Snježana ZRINJAN, Književnost 3 (čitanka za 3. razred četverogodišnjih strukovnih škola), Alfa, Zagreb, 2008.

\section{Internetski izvori}

Nacionalni centar za vanjsko vrednovanje znanja, URL: https://www.ncvvo.hr/drzavnamatura-2019-2020-ljetni-rok-3/) (12-24-2019)

\section{THE NOVEL POSLJEDNJI STIPANČIĆI BY VJENCESLAV NOVAK IN THE TEACHING OF SECONDARY SCHOOL}

\section{Summary}

In the history of Croatian literature, Vjenceslav Novak is presented as a realistic writer of the littoral environment, with an emphasis on his origins, work at school, material living conditions and the themes that he took mostly from the real world. Novak was an objective realistic narrator because he did not exalt or despise, yet at the same time, he was socially sensitive because he was the first one to bring his love for family and language into Croatian realism, with which he created a novel titled Posljednji Stipančići (The Last Stipančićs). It is obvious that the beauty of the selected words contributed to the fact that throughout the narration of the family story about the Stipančićs, the safe strokes of the writer's pen are felt, whether he talks about it chronologically or retrospectively.

The criticism of the realism had no understanding of Novak's huge opus as a result of a distinctive artistic creative force. Modern Croatian literary criticism has shown the growth of Novak's opus over four concentric circles. Since each literary work is a special correlation between the world that the writer depicts and the language in which he writes about that world, the logical connection is Novak's social and linguistic sensitivity as he tells the life story of a family of his time. In contemporary literary criticism, the novel The Last Stipančićs was proclaimed as the best novel of Croatian realism, it was present in secondary school literature classes, and last school year and at the state matura.

Keywords: family novel, realistic method, dictionary, social compassion 